\title{
Raccoon use of the urban matrix in the Baltimore Metropolitan Area, Maryland
}

\author{
Justin Gross • François Elvinger • \\ Laura L. Hungerford • Stanley D. Gehrt
}

Published online: 23 November 2011

(C) The Author(s) 2011. This article is published with open access at Springerlink.com

\begin{abstract}
The raccoon is often considered a synanthropic species; however, most urban research on this species has been restricted to urban parks or green spaces. Little is known about the persistence of synanthropic characteristics in the raccoon within the urban matrix. We examined density, den selection, home range size, habitat selection, and survival for adult raccoons (Procyon lotor) during summer (June-August) and autumn (September-November) in two residential neighborhoods, Linthicum located inland, and Riviera Beach on a peninsula in the Potomac river, in Southern Maryland. Den site selection varied by gender $(P=0.0002)$ and study site $(P=0.052)$, and study site interacted with gender $(P=0.0063)$, with female raccoons denning preferentially on the ground and male raccoons in human structures in Riviera Beach while in Linthicum females denned preferentially in trees and males avoided human structures. Seasonal home range size was larger for males $(P<0.0001)$ than females at both sites. Habitat selection varied at different hierarchical levels, and between gender, season and site. Intersite differences in habitat selection were apparent at the second order and third order scale. Aquatic and urban habitat was ranked high and woodland consistently lowest in second order scale at Riviera Beach while urban habitat was consistently ranked lowest at Linthicum where woodland ranked highest. Between the hierarchal scales (2nd and 3rd order) a difference in habitat selection occurred at Linthicum only where urban habitats ranked lowest at 3rd order. The differences in patterns of habitat selection we observed between two urban sites at different hierarchical scales suggest that resource selection is dependent upon the specific characteristics of the site and that raccoons exhibit variable responses to changes in landscape features. Finally, male survival tended to be lower $(P=0.079)$ than female
\end{abstract}

J. Gross $\cdot$ F. Elvinger

Virginia Maryland Regional College of Veterinary Medicine, Virginia Tech, Phase 2 Duck Pond Drive, Blacksburg, VA 24061, USA

\section{L. Hungerford}

University of Maryland School of Medicine, 655 West Baltimore Street, Baltimore, MD 21201, USA

\section{S. D. Gehrt $(\bowtie)$}

School of Environment and Natural Resources, Ohio State University, 2021 Coffey Road, Columbus, $\mathrm{OH} 43210$, USA

e-mail: gehrt.1@osu.edu 
survival in both study sites. Our results reveal that raccoons can continue to exhibit synanthropic characteristics within the urban matrix even in areas with little natural habitat. This ability to adjust to different levels of development allows the raccoon to occur throughout most parts of the urban landscape, which has important management implications for human-raccoon conflicts and disease management.

Keywords Denning - Density $\cdot$ Habitat selection $\cdot$ Home range $\cdot$ Procyon lotor $\cdot$ Raccoon Survival $\cdot$ Urbanization

\section{Introduction}

Urbanization greatly alters landscapes and ecological processes, such that many native species decline or disappear from urban areas whereas some species appear to increase in abundance (DeStefano and DeGraaf 2003; Blair 2004; Burton and Samuelson 2008; Gehrt 2010). Most attention from conservationists and urban planners has focused on species that are threatened by urbanization; however, a better understanding of how presumably urbanadapted, or synanthropic (Gliwicz et al. 1994; Johnstone 2001; McCleery et al. 2008; Withey and Marzluff 2009), species use the urban landscape is warranted. Gliwicz et al. (1994) predicted that synanthropic species should exhibit certain responses to urbanization, such as inceased densities, smaller home ranges, and higher reproductive or survival rates, when compared to the populations in natural or rural landscapes. For example, mammalian mesocarnivores are known to respond positively to urbanization to varying degrees (Prange and Gehrt 2004; Iossa et al. 2010), and these species commonly conflict with the public through property damage or health risks (Gehrt 2004; DeStefano and Deblinger 2005; Curtis and Hadidian 2010).

The raccoon (Procyon lotor) appears to be capable of exploiting urban landscapes, having been reported occupying urban areas over 100 years ago (Hadidian et al. 2010), and may be considered synanthropic (sensu Gliwicz et al. 1994). Raccoons have been observed readily utilizing anthropogenic resources, such as refuse for food and human structures for dens (Gehrt 2003; Hadidian et al. 2010), and population densities reported for urban areas have consistently been high when compared to rural areas (Rosatte et al. 1991; Riley et al. 1998; Prange et al. 2003). Likewise, home ranges are relatively small in size for raccoons in urban areas which, when combined with high population densities, produces an abundance that tends to exceed other mesocarnivores (Prange et al. 2004; Prange and Gehrt 2004).

Landscape-scale studies have suggested that raccoons are relatively unaffected by urban development compared to other mammalian carnivores (Crooks 2002; Randa and Yunger 2006), although Broadfoot et al. (2001) identified metapopulation structure in urban Toronto, with subpopulations centered on patches of woodland habitat. Indeed, urban raccoon populations appear to occur at their highest densities in woodland fragments embedded within the urban matrix (Rosatte et al. 1991; Riley et al. 1998; Prange et al. 2003). It is important to note that most of the information on the urban ecology of raccoons, especially via radiotelemetry, has come from research focused on these natural fragments, such as urban parks or preserves. Little is known as to how raccoons use the urban matrix (e.g., residential, commercial, and industrial areas), and whether the patterns observed for raccoons associated with urban parks are similar to the urban landscape.

A better understanding of raccoon use of the urban matrix has important practical implications. Raccoons host a variety of zoonoses, most notably raccoon strain rabies, which has presented a management challenge in urban areas across the eastern United 
States. Similarly, exposure to another raccoon zoonotic disease agent, raccoon roundworm (Baylisascaris procyonis), is most likely to occur in the urban matrix, such as residential neighborhoods adjacent to forested parks (Page et al. 2008). Property damage is also an important issue, as raccoons also are one of the predominant nuisance wildlife species in cities across North America (Gehrt 2003).

Home range size is closely tied to resource distribution and abundance, and can be an indicator of how well a species adjusts to the urban landscape. A typical prediction would be that smaller home ranges reflect a relatively high quality landscape, in which resources are abundant, compared to a landscape with larger home ranges (Gliwicz et al. 1994). The relatively small home range sizes reported for raccoons residing within urban forest patches suggests that resources are readily available (Bozek et al. 2007). However, little is known as to how raccoons exploit the urban matrix outside urban parks. Other mesocarnivores (e.g., coyotes [Canis latrans]) exhibit a positive relationship between home range size and the proportion of the home range that spans urbanized land (Riley et al. 2003; Gehrt et al. 2009), suggesting a cost to living in an urban landscape. However, if raccoon home range size does not increase with urbanization, this would suggest they are synanthropic (Gliwicz et al. 1994) and capable of effectively exploiting various parts of the urban landscape.

Synanthropy should also be manifested through demographic processes such as enhanced survival relative to rural areas (Gliwicz et al. 1994; McCleery et al. 2008). However, little information is available on survival of raccoons within the urban matrix, or how mortality factors may shift with urbanization. Raccoons in urban areas are protected from hunting and trapping, but are exposed to vehicular traffic and pathogens that may spill over from domestic or native species (Prange et al. 2003; Hadidian et al. 2010).

Our overall objective was to determine how raccoons use the urban matrix in a metropolitan area. Thus, we monitored raccoons at two urban sites that differed in the availability of natural habitat relative to the urban matrix, with a special focus on raccoons that resided largely in the urban matrix as opposed to a natural fragment. Our specific objectives were to 1) compare den type use by raccoons between sites, 2) compare home range size between sites, season, and gender, 3) determine raccoon habitat selection at two spatial scales, 4) determine the relationship between home range size and urbanization within the home range, and 5) estimate survival and identify causes of mortality between sites.

\section{Materials and methods}

\section{Study area}

We focused our fieldwork in two urban study sites in the Baltimore Metropolitan Area in Anne Arundel County, Maryland (Fig. 1). The primary features of both study sites were residential blocks with small commercial / industrial areas and isolated patches of woods and grassland, however they differed in that one site had larger, contiguous woodland fragments whereas the other did not. This research was part of a larger project focused on modeling rabies dynamics in urban raccoons, and information was needed for raccoons residing in areas dominated by development. We were also lacking information from the city core, but found the core area logistically prohibitive.

One study site, Linthicum, included 798 ha located approximately $13 \mathrm{~km}$ southwest of downtown Baltimore. Urban development comprised $73 \%$ of the study area's landscape, including 2,950 housing units and 7,539 residents (U.S. Bureau of the Census 2000). 


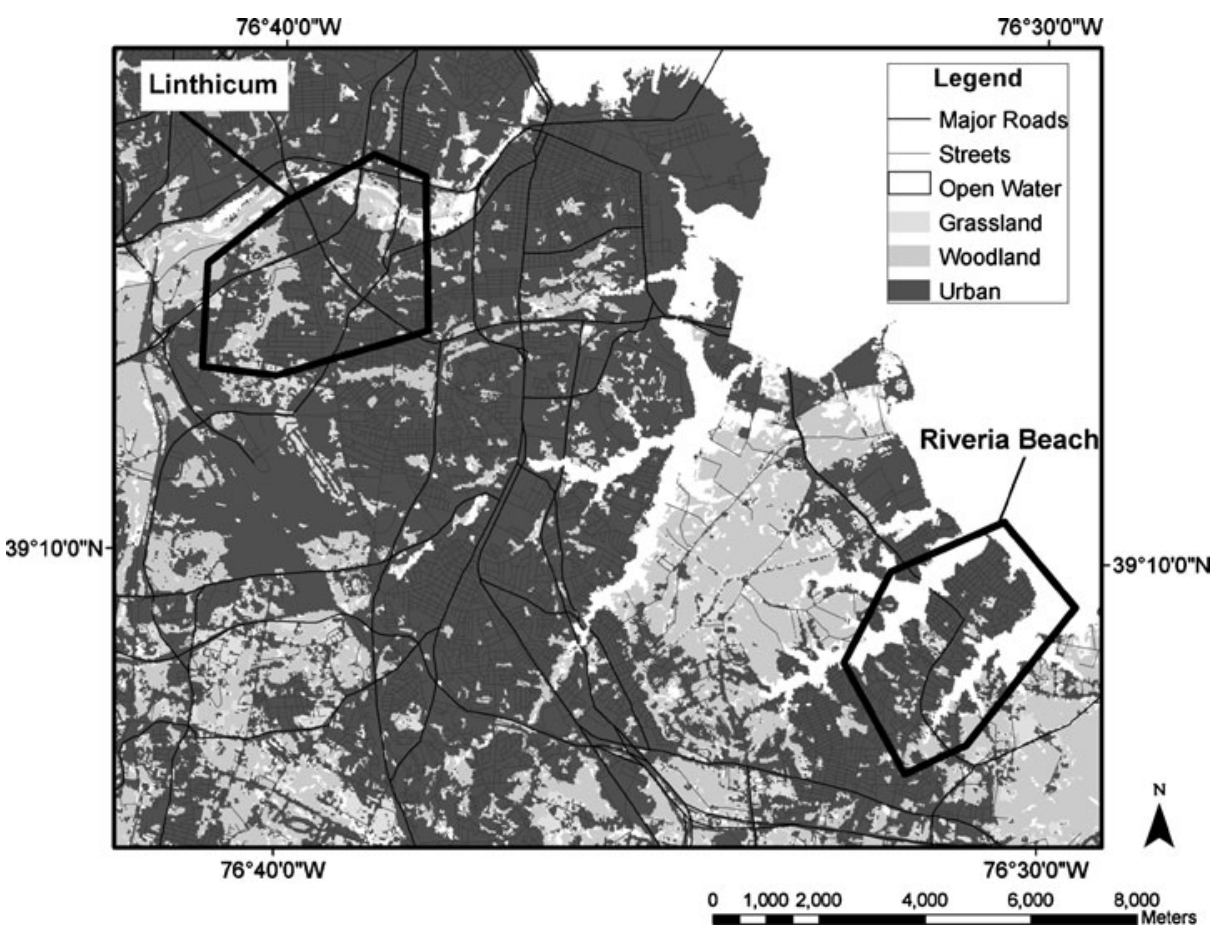

Fig. 1 Location of study sites within the larger Baltimore metropolitan area, Maryland, U.S. Boundaries were delineated by encompassing radiolocations of radiocollared raccoons, pooled across seasons

Linthicum had a high traffic volume as it was bisected by a major interstate with an annual average daily traffic (AADT) of 131,524 cars (Maryland Department of TransportationState Highway Administration 2007), 4 state highways (AADT's of 88,860, 12,327, 14,461 , and 16,861 cars), with another interstate (AADT of 23,929 cars) and state highway (AADT of 6,167 cars) along edges and numerous secondary roads, with a resulting road density of $7 \mathrm{~km}$ of road per $\mathrm{km}^{2}$. This site was bisected by a stream and a contiguous fragment of woodland habitat (Fig. 1).

The second study site, Riviera Beach, included 1,055 ha on a peninsula into the Chesapeake Bay, located approximately $21 \mathrm{~km}$ southeast of the City of Baltimore on a small peninsula in the Chesapeake Bay (Fig. 1). Most of the land cover within the site was urban development (76\%) with 4,950 housing units and 12,695 residents (U.S. Bureau of the Census 2000). A state highway bisected the area, with an annual average daily traffic (AADT) volume of 13,734 cars (Maryland Department of Transportation-State Highway Administration 2007). Two additional more peripherally located state highways with AADT's of 20,911 and 15,667 cars) and other secondary roads in the study area gave a road density of $11 \mathrm{~km}$ of road per $\mathrm{km}^{2}$. Although this site was somewhat similar to Linthicum regarding the level of development, woodland habitat only occurred as many small fragments scattered across the site.

\section{Raccoon capture}

We captured and handled raccoons in accordance with guidelines set by the Institutional Animal Care and Use Committee, permit \#99-060-CVM of Virginia Tech and \#0704004 of the University of Maryland, Baltimore. Raccoons were trapped with live traps (Tomahawk 
Live Trap Co., Tomahawk, WI) that were baited with commercial canned cat food. We placed traps within a $2.88 \mathrm{~km}^{2}$ grid with two traps per grid cell for a total of 36 traps, placed throughout the study areas from August through September 2006 and April through September 2007. To maximize capture rates, we placed traps along logs, water edges and travel routes. Raccoons were immobilized with $0.2 \mathrm{ml}$ of Telazol ${ }^{\mathrm{R}}$, (Fort Dodge Animal Health, Fort Dodge, Iowa) weighed, measured, sexed and aged by tooth wear (Grau et al. 1970). We marked all captured raccoons with Monel \# 4 ear tags (National Band and Tag Company, Newport, Kentucky) and adult raccoons were fitted with a radiocollar (Advanced Telemetry Systems, Isanti, Minnesota). By the start of the study in summer 2007, 8 male and 8 female $>1$-year old raccoons had been fitted with radiocollars in each of the two study sites. In case of loss of a radiocollared raccoon, a new gender-matched raccoon was trapped and fitted a radiocollar such that 16 radiocollared raccoons $(8 \mathrm{~F}, 8 \mathrm{M})$ were maintained at each study site throughout most of the study. By the conclusion of the study a total of 43 raccoons had been fitted with a radiocollar.

Density estimates for each site were estimated from initial trapping periods (10 days) with the heterogeneity model $\mathrm{M}(\mathrm{h})$ in program Mark (White and Garrott 1990), using CAPTURE (Otis et al. 1978). We used a closed population model because we assumed limited immigration/emigration and death during the 10-day period. The heterogeneity model is the most appropriate model for raccoons because the probability of capture typically varies among individuals, especially with gender (Gehrt and Fritzell 1996). Density estimates were derived from minimum trapping area, which is defined as the total area used by raccoons from radiotelemetry data during the initial 10-day trapping period in August and September 2006.

\section{Landcover}

Landcover was categorized into four habitat types which were urban (residential neighborhoods, industrial, roads and schools), woodland (includes deciduous and evergreen), grassland (open areas, not delineated as agriculture), and aquatic (lakes, ponds, and wetlands; streams and rivers). Orthophotographs and the 2001 United States Geological Survey Land Use Map were overlaid in Arcmap 9.2 to create a habitat map of Anne Arundel County, Maryland. Study site boundaries were set by combining all raccoon telemetry locations using the minimum convex polygon (MCP) method (Mohr 1947). Linthicum landcover was urban (580 ha, 73\%), woodland (156 ha, 20\%), aquatic (23 ha, $3 \%$ ) and grassland (39 ha, 5\%). Landcover in Riviera Beach included urban (802 ha, 76\%), woodland (131 ha, 12\%), aquatic (86 ha, $8 \%$ ) and grassland (35 ha, 3\%).

\section{Radiotelemetry}

Diurnal locations were obtained for each raccoon once a week by homing in on raccoon den sites using handheld three-element yagi antennae and marking locations with a handheld GPS receiver (Garmin International, Inc., Olathe, Kansas). Nocturnal locations were collected each week on three or four nights. Locations were determined at one or two-hour intervals for three to four individual locations per raccoon per night (McNay et al. 1994; Gehrt and Fritzell 1997). Home ranges were calculated for all raccoons with $\geq 30$ locations during the 2007 season, however typically $>40$ locations were collected for each raccoon (Seaman et al. 1999) for each season. We partitioned radiotelemetry data into summer and autumn seasons. Summer was defined as June through August, when young are weaned and move out of the den (Sanderson and Nalbandov 1973). September through November was considered fall, when 
juveniles are moving independently (Schneider et al. 1971). Locations with maximum angle intersection $<45^{\circ}$ and minimum $>135^{\circ}$, and locations with an error polygon $>4.0$ ha were excluded from analyses to reduce location error. Approximate precision of bearings and triangulation of error was $2.18^{\circ} \pm 0.12$ and $122 \mathrm{~m} \pm 7.4$ for Linthicum and $2.10^{\circ} \pm 0.15$ and $75 \mathrm{~m} \pm 3.7(X \pm \mathrm{SE})$ for Riviera Beach, as determined from 1,345 bearings on 41 test collar locations. All locations were recorded in Universal Transverse Mercator (UTM) coordinates. Raccoon location estimates were calculated using Location Of A Signal software (LOAS 4.0.3.1; Ecological Software Solutions LLC, Florida).

Den site analyses

Structure types associated with daytime locations for raccoons were recorded for each season and placed into four categories: human structure, sewer, ground dens, and tree (usually a tree cavity). In addition, categories for ground and trees were separated into either woodland or residential types for analysis. Effects of gender, season and study site on den selection were evaluated by multinomial regression using the Generalized Estimating Equations in Proc Genmod of SAS ${ }^{\mathrm{R}}$ (Cary, North Carolina).

\section{Home ranges}

Home ranges for each raccoon and season were defined using the Animal Movement Extension in Arcview 3.3 (Hooge and Eichenlaub 1997) for calculation of the $50 \%$ and $95 \%$ fixed kernel home range estimates, using the biased cross validation method to smooth the contours of the $50 \%$ core and $95 \%$ home ranges (Worton 1989). Effects of gender, site and season on home range size were evaluated by analysis of variance using the Mixed procedure of $\mathrm{SAS}^{\mathrm{R}}$ (Cary, North Carolina).

Habitat type selection analysis

Habitat type selection by raccoons was evaluated by compositional analysis. In second order habitat type selection (Johnson 1980), non-random use of habitat type was differentiated from random use of available habitats within the study area, taking log ratios of available and used habitats and comparing the matrices of log ratios (Aebischer et al. 1993). Habitat types were ranked in order of preference using bycomp.sas (Ott and Hovey 1997). Logarithmic transformation of values in compositional analysis requires each animal to use every available habitat type; in case of non-use of a habitat type by individual animals, we replaced $0.0 \%$ use with $0.3 \%$ use for second order habitat type selection (Bingham and Brennan 2004), which were calculated for $95 \%$ home range by study site, season and gender.

Third order habitat type selection refers to the relative use of habitat types within the home range (Johnson 1980). At this spatial scale, proportions of telemetry locations within habitat types are compared to the availability of those habitat types within the home range. Due to sample size limitations, raccoons were pooled across gender for $95 \%$ home range third order habitat type selection. Raccoons not recorded in one or more of the four available habitat categories were removed from third order calculations.

Urbanization and home range size

We used simple linear regression to determine the relationship between the level of urbanization within a home range and home range size by determining the composite 
proportion of urban categories within a seasonal home range, and regressing this metric with home range size at the $95 \%$ and $50 \%$ contours. To satisfy assumptions of normality, we log-transformed home range size and arcsine-square root transformed the proportion of cumulative urban-associated land use.

\section{Survival}

We estimated survival rates for the duration of the project (17 months). We partitioned causes of mortality into the following categories: vehicle collisions, disease, other, or unknown. Survival estimates and cause-specific mortality rates were estimated with MICROMORT (Heisey and Fuller 1985). Associations of survival and cause of death with study site and gender were evaluated by logistic regression using Proc Logistic of $\mathrm{SAS}^{\mathrm{R}}$ (Cary, NC).

\section{Results}

During initial trapping sessions (10 nights), we captured 14 individual raccoons $(7 \mathrm{M}$, $4 \mathrm{~F}$ adults; $2 \mathrm{M}, 1 \mathrm{~F}$ juveniles) at Linthicum, and 33 individual raccoons (10 M, $7 \mathrm{~F}$ adults; $10 \mathrm{M}, 6 \mathrm{~F}$ juveniles) at Riviera Beach. Our density estimate for Riviera Beach was $66(\mathrm{SE}=14.2) \mathrm{raccoons} / \mathrm{km}^{2}$, and $34(\mathrm{SE}=10.1) \mathrm{raccoons} / \mathrm{km}^{2}$ at Linthicum. After the initial 10-day trapping period, we captured an additional 11 adults (7 M, $4 \mathrm{~F})$ and 4 juveniles $(3 \mathrm{M}, 1 \mathrm{~F})$ at Linthicum; and 7 adults $(5 \mathrm{M}, 2 \mathrm{~F})$, and 1 male juvenile at Riviera Beach. Gender and age distribution were similar (Fisher's Exact $p>0.2$ ) between study sites.

Den sites

Den sites were determined for 31 raccoons on 337 raccoon-days. In Linthicum determinations were made for 13 raccoons on 101 raccoon-days in summer and 14 raccoons on 38 raccoon-days in fall, with 13 raccoons observed in both seasons. In Riviera Beach determinations were made for 15 raccoons on 125 raccoon-days in summer and 15 raccoons on 73 raccoon-days in fall, with 13 raccoons observed in both seasons. Den sites were categorized as human structures, which included houses and chimneys, garages, sheds, and other structures (abandoned house trailer, car, boat); ground sites, either in public woods, residential yards, or along the water's edge mostly in residential yards; tree sites, either in public woods or residential yards; and sewer (Table 1). Gender affected den site selection by raccoons, when analyzing dennings by major category $(P=0.0002)$. While about one third of recorded dennings for both males and females were in trees, $45 \%, 15 \%$ and $5 \%$ of female dennings, and $13 \%$, 36 and $19 \%$ of male dennings were on the ground, in human structures, or in the sewer system, respectively. Study site affected den choice $(P=0.052)$, while season did not and was removed from the final model. Den choice differed for females and males in the two study sites (gender x study site, $P=0.0063$ ), with $59 \%$ of detected female dennings in trees and only $28 \%$ on the ground in Linthicum, but $57 \%$ on the ground in Riviera Beach and only $17 \%$ of detected female dennings in trees. For males $56 \%$ of dennings in Riviera Beach, but only $6 \%$ in Linthicum were in human structures, and therefore the proportions of dennings on the ground ( $25 \%$ vs $5 \%$ ), in trees $(41 \%$ vs. $27 \%)$ or in sewers $(28 \%$ vs. $12 \%)$ were higher for males in Linthicum than in Riviera Beach. 
Table 1 Den site types of 31 raccoons on 337 raccoon-days during summer-autumn 2007 in two urban study sites (Riviera Beach and Linthicum) in Anne Arundel County, Maryland

\begin{tabular}{lll}
\hline Den Type & Linthicum & Riviera Beach \\
& $n(\%)$ & $n(\%)$ \\
\hline
\end{tabular}

\begin{tabular}{llll} 
Human Structure & & & \\
Above ground & House/Chimney & 4 & 29 \\
& Shed & 3 & 38 \\
& Garage & 0 & 5 \\
& Other $^{\mathrm{a}}$ & 0 & 8 \\
& Total & $7(5)$ & $80(40)$ \\
Below ground & Sewer & $25(18)$ & $15(8)$ \\
Ground den & Woods & 26 & 11 \\
& Residential & 11 & 19 \\
& Water-edge & 0 & 29 \\
Tree cavity & Wotal & $37(27)$ & $59(30)$ \\
& Woods & 60 & 20 \\
Total & Residential & 10 & 24 \\
\hline
\end{tabular}

${ }^{a}$ other included boat, car, house trailer, and under pool

Home range

We determined home ranges from 3,578 locations for 34 raccoons, 17 of which $(9 \mathrm{M}, 8 \mathrm{~F})$ were in Linthicum and $17(9 \mathrm{M}, 8 \mathrm{~F})$ in Riviera Beach. Home range size varied by study site $(95 \%$ contour, $P=0.003$, and $50 \%$ contour, $P=0.032)$, gender $(P<0.0001$ and $P<0.0001$, respectively), and there was a season $\mathrm{x}$ gender interaction $(P=0.041$ and $P=0.043$, respectively). Mean home range size was larger at Linthicum than at Riviera Beach for $95 \%$ and $50 \%$ contours. Male home ranges were consistently larger than female home ranges regardless of site or season, but males reduced home range size during autumn whereas female home range size increased from summer to autumn. (Table 2).

Proportion of urban landcover within home ranges did not differ between genders $(P=0.4768)$, but proportion of urban landcover within home ranges differed between study sites $(P<0.0001)$. Urban landcover comprised $48 \%$ of male $(\mathrm{SD}=17 \%)$ and $45 \%$ of female $(\mathrm{SD}=21 \%)$ home ranges in Linthicum and $71 \%$ of male $(\mathrm{SD}=20 \%)$ and $70 \%$ of female $(\mathrm{SD}=14 \%)$ home ranges in Riviera Beach (Fig. 2).

\section{Habitat selection}

At the Linthicum site, second order home range habitat use differed from availability for males and females in both seasons (Table 3). Woodland habitats ranked highest for both sexes during both seasons, and urban areas were avoided by males and females in each season (Fig. 3).

Second order selection was evident at the Riviera Beach site for females during both seasons and for males during autumn but not for summer (Table 3). Urban areas were selected higher than grassland and woodland habitats (Fig. 3).

At third order home range scale, habitat use differed from availability at both sites during autumn and also during summer at Linthicum(Table 3).. In Linthicum, woodland and urban 
Table 2 Mean 95\% home range and 50\% core fixed kernel estimates for 18 male and 16 female raccoons in summer and autumn 2007 at two urban study sites, Linthicum and Riviera Beach, Anne Arundel County, Maryland

\begin{tabular}{|c|c|c|c|c|c|}
\hline \multirow[t]{2}{*}{ Study Site } & \multirow[t]{2}{*}{ Season } & \multicolumn{2}{|l|}{ Male } & \multicolumn{2}{|l|}{ Female } \\
\hline & & Mean (ha) & $95 \% \mathrm{CI}$ & Mean (ha) & $95 \% \mathrm{CI}$ \\
\hline \multicolumn{6}{|l|}{$95 \%$ Contour } \\
\hline \multirow[t]{2}{*}{ Linthicum } & Summer & 103.3 & $65.7-162.4$ & 24.7 & $13.1-46.5$ \\
\hline & Autumn & 92.7 & $56.5-151.9$ & 53.0 & $23.1-121.5$ \\
\hline \multirow[t]{2}{*}{ Riviera Beach } & Summer & 94.1 & $56.1-157.7$ & 13.3 & $11.9-15.0$ \\
\hline & Autumn & 54.9 & $42.9-70.2$ & 14.2 & $11.9-16.9$ \\
\hline \multicolumn{6}{|l|}{$50 \%$ Contour } \\
\hline \multirow[t]{2}{*}{ Linthicum } & Summer & 16.3 & $10.1-26.4$ & 3.8 & $2.4-6.0$ \\
\hline & Autumn & 10.3 & $6.3-17.0$ & 4.7 & $2.8-7.9$ \\
\hline \multirow[t]{2}{*}{ Riviera Beach } & Summer & 15.1 & $7.0-33.0$ & 1.7 & $1.4-2.1$ \\
\hline & Autumn & 6.3 & $4.3-9.3$ & 2.1 & $1.3-3.4$ \\
\hline
\end{tabular}

areas were selected at a greater difference at 2 nd order home range scale than aquatic and grassland habitats while in Riviera Beach aquatic and woodland habitats were selected at greater difference than other habitat types (Fig. 3). At the third order scale, woodland and grassland in Linthicum during summer, woodland and urban in Linthicum during autumn,

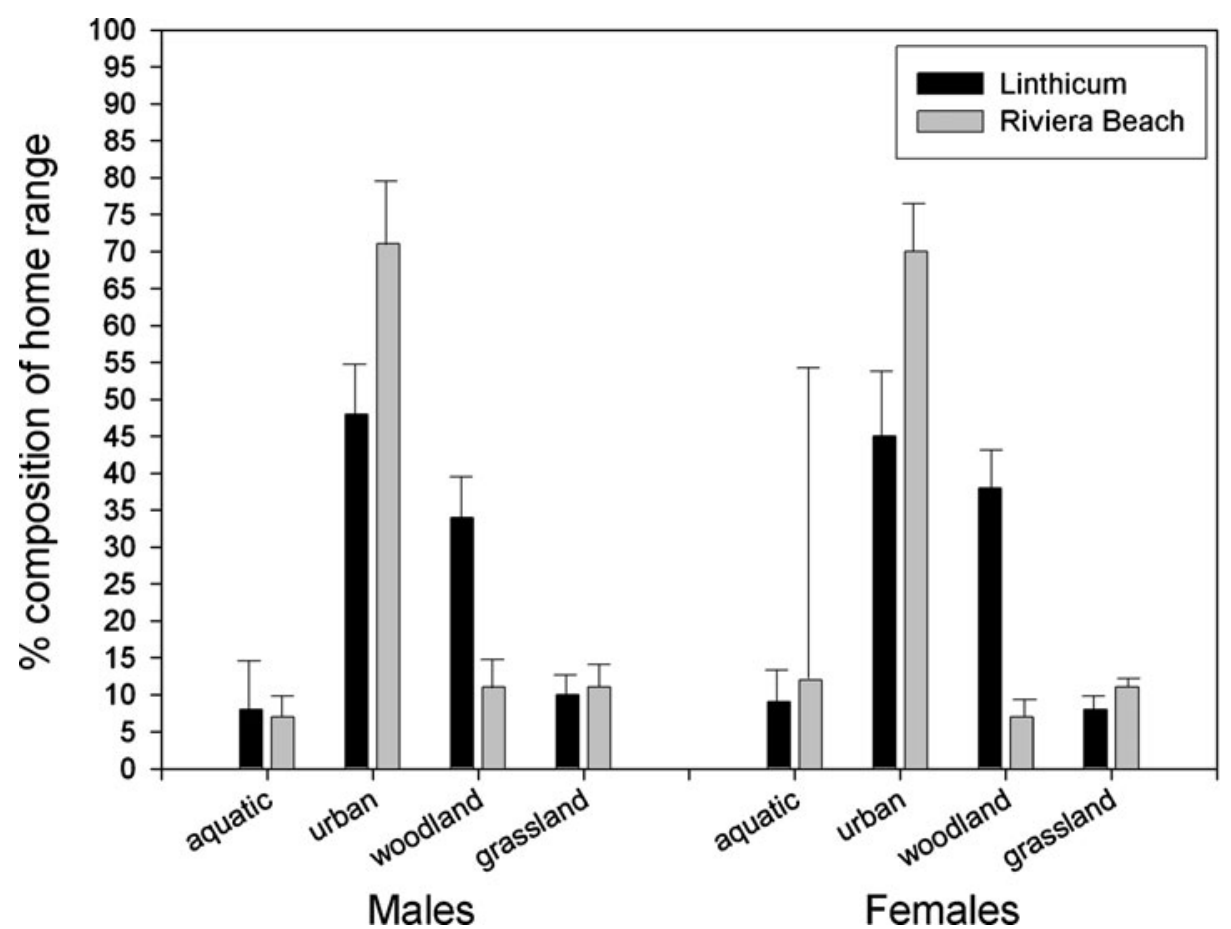

Fig. 2 Mean composition of habitats within home ranges for raccoons $(n=34)$ at two study sites, Linthicum and Riviera Beach, in Anne Arundel County, Maryland. Whiskers are upper 95\% confidence intervals 
Table 3 Compositional analysis results for raccoons habitat use with seasonal $\mathrm{f}$-values, degrees of freedom and p-values (raccoon habitat use did not differ from availability) in Anne Arundel County, Maryland (summer 2007-fall 2007)

\begin{tabular}{lllccc}
\hline Study Site & Season & Gender & $F$ & df & $P$ \\
\hline \multirow{2}{*}{ Linthicum } & & \multicolumn{3}{c}{ Second Order Home range } \\
& Summer & Male & 9.38 & 3,6 & 0.0111 \\
& Autumn & Female & 13.68 & 3,4 & 0.0143 \\
& & Male & 48.19 & 3,4 & 0.0013 \\
Riviera Beach & Fummer & Male & 31.20 & 3,4 & 0.0031 \\
& & Female & 2.74 & 3,5 & 0.1528 \\
& Autumn & Male & 13.00 & 3,4 & 0.0337 \\
& & Female & 16.60 & 3,4 & 0.0157 \\
& & & Third Order Home range & 0.0050 \\
Riviera Beach & Summer & & 2.20 & 3,8 & 0.1658 \\
& Autumn & & 7.16 & 3,6 & 0.0208 \\
Linthicum & Summer & & 3.39 & 3,13 & 0.0507 \\
& Autumn & & 4.00 & 3,11 & 0.0375
\end{tabular}

and aquatic and woodland in Riviera Beach during autumn were selected for use by raccoons (Fig. 4).

\section{Urbanization and home range size}

We did not observe a relationship between $95 \%$ home range contours and urbanization for summer $(\mathrm{R}=0.077, n=31, P=0.68)$ or fall $(\mathrm{R}=-0.139, n=28, P=0.479)$. However, there were negative trends between size of $50 \%$ contours and proportion of urbanization in the $95 \%$ home range for both seasons (summer: $\mathrm{R}=-0.30, n=31, P=0.10$; fall: $\mathrm{R}=-0.47, n=28, P=0.01$ ).

\section{Survival}

Of 16 recorded mortalities in 12 of 25 collared males and 4 of 18 collared females, 9 were caused by vehicular collision, 3 by disease ( 2 rabies and 1 pneumonia) and 3 by accident ( 1 found dead in large pipe; 2 shot) (Table 4). One fatality was due to unknown

Table 4 Raccoon survival estimates and causes of mortality in two urban areas during September 2006January 2008 in Anne Arundel County, Maryland

\begin{tabular}{lllllcccc}
\hline Site & Gender & $n$ & $\hat{\mathrm{s}}$ & $95 \%$ C.I. & Vehicle Collision & Disease & Other $^{\mathrm{a}}$ & Unknown $^{2}$ \\
\hline Linthicum & Male & 14 & 0.381 & $0.163-0.662$ & 6 & 1 & 1 & 0 \\
& Female & 10 & 0.666 & $0.335-0.888$ & 0 & 2 & 1 & 1 \\
\multirow{2}{*}{ Riviera Beach } & Male & 11 & 0.524 & $0.251-0.783$ & 3 & 0 & 1 & 0 \\
& Female & 8 & 1 & $0.008-1$ & 0 & 0 & 0 & 0 \\
\hline
\end{tabular}

a 'other' included fell into pipe $(n=1)$ and shot $(n=2)$ 

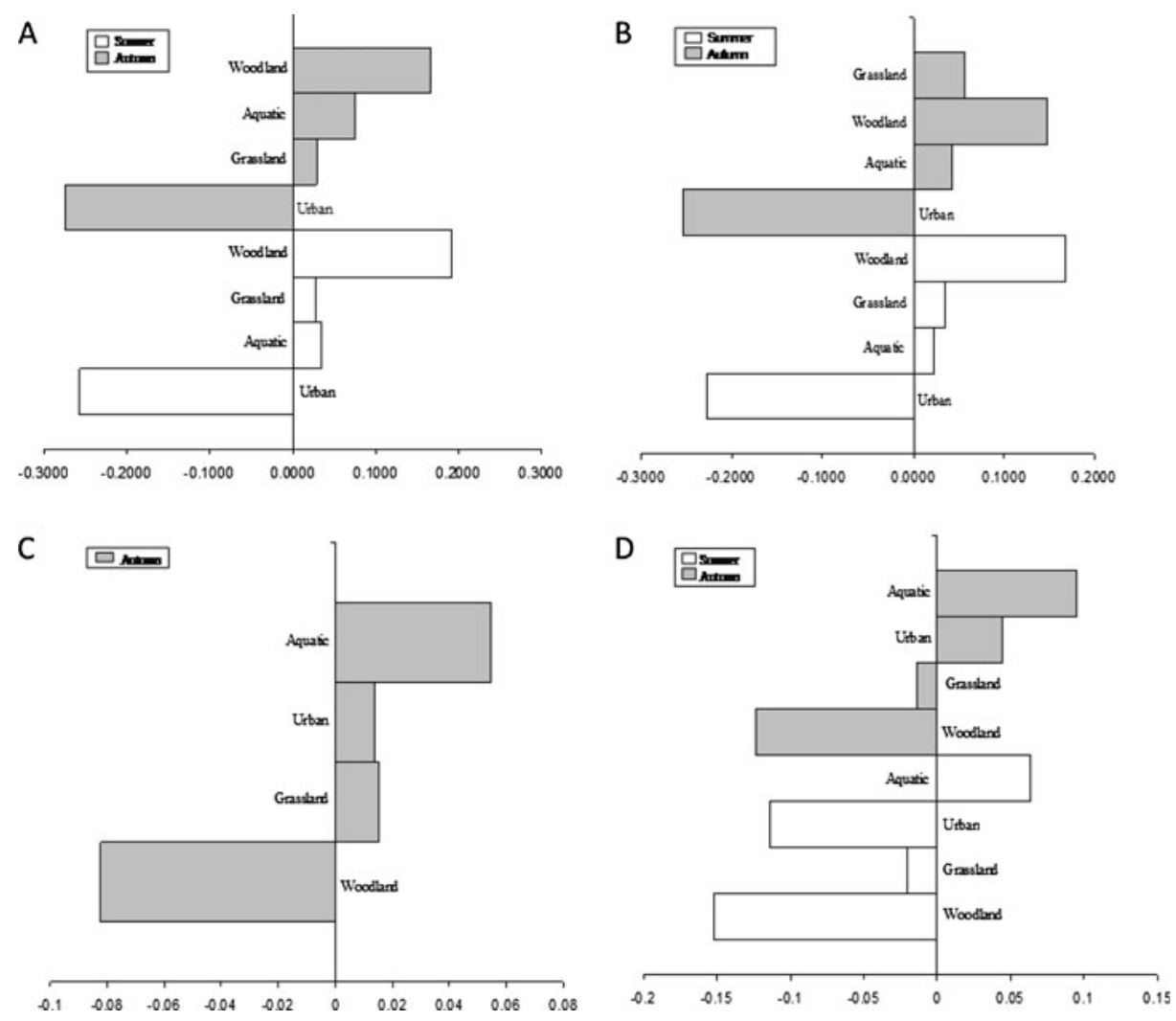

Fig. 3 Rankings of habitat selection and direction of selection, at the 2nd order home range scale for raccoons at Linthicum and Riviera Beach, Anne Arundel County, Maryland. June-November 2007. Panel A, 95\% Linthicum Male; Panel B, 95\% Linthicum Female; Panel C, 95\% Riviera Beach Male; Panel D, 95\% Riviera Beach Female

causes. Mortalities tended to differ by study site $(P=0.051)$ and gender $(P=0.079)$ with odds of raccoons dying in Linthicum being 4.2 (95\% confidence interval: $[0.996 ; 17.34])$ times the odds of raccoons dying in Riviera Beach and odds of males dying $3.6[0.86 ; 15.38]$ times the odds of females dying. Among dead raccoons gender and death by car accident were associated $(P=0.019)$ with nine of 12 deaths in males and none of four deaths in female raccoons being related to car accidents.

\section{Discussion}

Although the raccoon has long been associated with urban areas (Hadidian et al. 2010), our study provides important insight into how raccoons exploit the urban matrix without the benefit of large woodland habitat fragments or preserved open space. Our results provide multiple lines of evidence that raccoons operate as a synanthropic species in the suburban Baltimore area, even in the urban matrix with reduced woodland habitat.

Our density estimates are within the range reported for raccoons in urban areas, which have ranged between 38-125 raccoons $/ \mathrm{km}^{2}$ (Hoffman and Gottschang 1977; Rosatte et al. 
Fig 4 Rankings of habitat selection and direction of selection, at the $3 \mathrm{rd}$ order home range scale for raccoons at Linthicum and Riviera Beach, Anne Arundel County, Maryland. June-November 2007. Panel A, 95\% Linthicum; Panel B, 95\% Riviera Beach

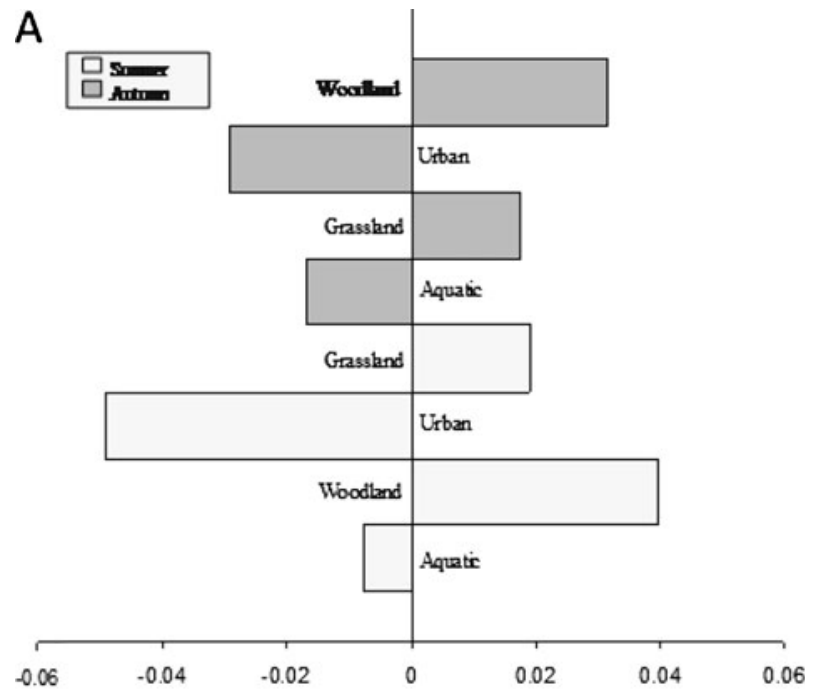

B

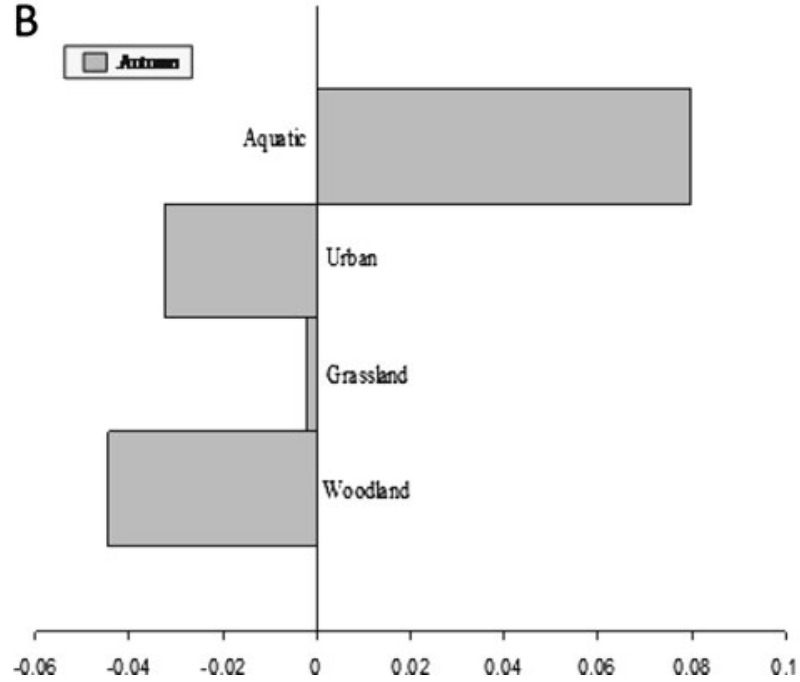

1990; Riley et al. 1998; Prange et al. 2003). However, these previous estimates are primarily for raccoons associated with urban parks or open spaces. Thus, any negative effect of urban development on raccoon populations was not evident by declines in abundance.

One method by which raccoons are able to exploit the urban matrix is through their selection of den types. The ability of raccoons to use a wide variety of den types is well documented (Gehrt 2003), and raccoons in our study used that flexibility to exploit the urban matrix. The use of den site structures varied between sites in our study, and reflected the relative lack of natural habitat available to the raccoons, especially at Riviera Beach. For example, a high percentage (48\%) of dennings at Riviera Beach were in human-related structures and $69 \%$ of all dennings were found in residential neighborhoods, while at Linthicum (a site with woodland habitat available in a contiguous fragment) $23 \%$ of the dennings were in human-related structures and only $15 \%$ of all dennings were in yards. 
Similarly, raccoons in natural systems have been observed to shift to ground dens or artificial structures when tree cavities are rare (Gehrt and Fritzell 1998).

Many of the biological phenomena that influence raccoon home range size in natural systems apparently maintained their influence in our Baltimore sites. The intersexual differences we documented in patterns of home range size are consistent with previous studies of raccoons in various types of landscapes. Male raccoons typically maintain larger home ranges than females, largely as a result of differences in reproductive strategies or constraints (Gehrt and Fritzell 1997). Likewise, the intersexual differences in seasonal shifts in home range size reflect reproductive constraints, in which adult females are restricted in their movements during the litter-rearing stage (summer) compared to male raccoons, and the female home ranges typically increase in size during autumn as young become independent (Gehrt and Fritzell 1997, 1998).

Home ranges in urban areas are assumed to be smaller than those in rural areas for species that are able to exploit highly clumped anthropogenic resources (Gliwicz et al. 1994; Ditchkoff et al. 2006; Iossa et al. 2010). As expected, home range sizes in our study were relatively small compared to home ranges reported for raccoons in natural or rural landscapes (generally >100 ha; Beasely et al. 2007; Gehrt and Fritzell 1997; Lehman 1984; Prange et al. 2004), but are similar to other urban studies of raccoons primarily in urban parks (generally < 100 ha; Bozek et al. 2007; Hoffman and Gottschang 1977; Prange et al. 2004; Rosatte et al. 1991). The lack of a relationship between home range size and the proportion of urbanization within home range in our study indicated that raccoons are capable of effectively exploiting the urban matrix. This result contrasts with other, less omnivorous species such as coyotes and bobcats (Lynx rufus), in which home ranges of these species increase in size in relation to the proportion of the home range composed of the urban matrix (Riley et al. 2003; Gehrt et al. 2009). However, urbanization and fragmentation may influence the internal dynamic of the raccoon home range, in which the size of the core area (50\% contour) exhibited a negative relationship with development. The smaller core area may reflect the reduced size of habitat fragments produced by more extensive development, in which raccoons localize their activities within smaller habitat patches and potential sources of predictable human food waste. The pattern of intraspecific variation in home range size is consistent with scent station surveys that report raccoons as relatively flexible to the urban landscape compared to other mammalian carnivores (Crooks 2002; Randa and Yunger 2006).

Multiple studies have reported scale-dependent habitat selection in raccoons (Beasley et al. 2007; Bozek et al. 2007; Chamberlain et al. 2003); however, none of these were focused exclusively in the urban matrix. Bozek et al. (2007) reported on habitat selection during foraging bouts in raccoons within a large urban park with substantial anthropogenic foods nearly continuously available. In that study, raccoons selected for human-related habitats and, unlike in rural landscapes, differences in habitat selection between sexes were minimal (Bozek et al. 2007). Patterns of habitat selection at both of our sites indicated that raccoons were selecting for habitat fragments within the larger urban matrix regardless of scale, but their use of urban areas differed by scale. At the Linthicum site, the availability of woodland fragments influenced the orientation of male and female home ranges, with both sexes strongly selecting for those habitat fragments while at the same time minimizing the use of the urban landscape. Raccoons at our most urbanized site, Riviera Beach, did not avoid urban areas at the home range scale, but selected for the most available natural habitat, in this case aquatic habitat. At the third order selection, within the home range, raccoons at Linthicum continued to exhibit selection for woodland habitat and avoidance of urban habitat; at Riviera Beach raccoons strongly selected for aquatic habitat and 
maintained strong avoidance of urban habitat. The difference in selection of urban habitat by scale suggests that raccoons regularly move through the urban matrix to exploit small fragments of habitat that may, or may not, have had anthropogenic foods associated with them.

As raccoons move across the urban matrix, they are exposed to mortality factors associated with humans, primarily vehicles. However, we did not observe an elevated cost to living in the urban matrix in the form of higher mortality. Survival rates between our sites were similar, despite the differences in apparent exposure to roads and traffic, which suggests that raccoons adjusted to risks imposed by traffic. Likewise, more vehicle-related deaths were reported for Linthicum, rather than Riviera Beach, despite a higher exposure to traffic for raccoons at Riviera Beach. Prange et al. (2003) also reported a similar trend, in which there was no association between level of urbanization and an increase in vehiclerelated mortality for raccoons in the Chicago area, although that study focused on raccoons living in parks and only on females. Our survival estimates should be compared to other studies with caution, as they represent survival of a small sample over a 17-month period; nevertheless, they are similar to annual survival estimates reported for raccoons in Toronto (0.40-0.50; Rosatte et al. 1991; Rosatte 2000), and similar or slightly lower than annual estimates of $0.63-0.88$ for raccoons in urban parks in Washington D.C. and Chicago (Riley et al. 1998; Prange et al. 2003).

Our results provide multiple lines of demographic and behavioral evidence supporting synanthropy for this species and illustrate how raccoons are capable of exploiting some types of urban matrix. These results also explain why raccoons are relatively insensitive to urban habitat fragmentation compared to other mammalian carnivores (Crooks 2002). However, given the limitation of two study sites from a single metropolitan area, our results only represent an initial step toward understanding the ecology of raccoons in the urban matrix. Recent research on commensal bird species demonstrated they actually exhibited highly variable spatial distributions across the Baltimore metropolitan area, despite their close association with urban areas and a perception of a ubiquitous distribution across the landscape (Pickett et al. 2008). Clearly, additional research on raccoons and other urbanassociated species is needed on a larger scale and in a variety of urban systems given the limitations of our study and the complexities of urban landscapes.

Acknowledgments The authors gratefully acknowledge the support for site selection and access of Dr. Joseph T. Horman and Mr. Kyle Shannon of the Anne Arundel County Health Department. Sakthi Subburayalu assisted with GIS analysis, Lynsey White produced Figure 1, and we appreciate helpful comments provided by S. Hauver on the manuscript. This project was supported by funding from the National Science Foundation, Award ID 0425203, and the Max McGraw Wildlife Foundation.

Open Access This article is distributed under the terms of the Creative Commons Attribution Noncommercial License which permits any noncommercial use, distribution, and reproduction in any medium, provided the original author(s) and source are credited.

\section{References}

Aebischer NJ, Robertson PA, Kenward RE (1993) Compositional analysis of habitat use from animal radiotracking data. Ecology 74:1313-1325

Beasley JC, DeVault TL, Rhodes OE (2007) A hierarchical analysis of habitat selection by raccoons in Northern Indiana. J Wildl Manag 71:1125-1133

Bingham RL, Brennan LA (2004) Comparison of type I error rates for statistical analysis of resource selection. J Wildl Manag 68:206-112 
Blair R (2004) The effects of urban sprawl on birds at multiple levels of biological organization. Ecol Soc 9:1-21

Bozek CK, Prange S, Gehrt SD (2007) The influence of anthropogenic resources on multi-scale habitat selection by raccoons. Urban Ecosyst 10:413-425

Broadfoot JD, Rosatte RC, O’Leary DT (2001) Raccoon and skunk population models for urban disease control planning in Ontario, Canada. Ecol Appl 11:295-303

Burton ML, Samuelson LJ (2008) Influence of urbanization on riparian forest diversity and structure in the Georgia Piedmont, US. Plant Ecol 195:99-115

Chamberlain MJ, Conner LM, Leopold BD, Hodges KM (2003) Space use and multi-scale habitat selection of adult raccoons in Central Mississippi. J Wildl Manag 67:334-340

Crooks KR (2002) Relative sensitivities of mammalian carnivores to habitat fragmentation. Conserv Biol 16:488-502

Curtis PD, Hadidian J (2010) Responding to human-carnivore conflicts in urban areas. In: Gehrt SD, Riley SPD, Cypher BL (eds) Urban carnivores: ecology, conflict, and conservation. The Johns Hopkins University Press, Baltimore, pp 201-211

DeStefano S, Deblinger RD (2005) Wildlife as valuable natural resources vs. intolerable pests: a suburban wildlife management model. Urban Ecosyst 8:179-190

DeStefano S, DeGraaf RM (2003) Exploring the ecology of suburban wildlife. Fronti Ecol Urban Environ 1:95-101

Ditchkoff SS, Saalfeld ST, Gibson CJ (2006) Animal behavior in urban ecosystems: modifications due to human-induced stress. Urban Ecosyst 9:5-12

Gehrt SD (2003) Raccoons and allies. In: Feldhamer GA, Thompson BC, Chapman JA (eds) Wild mammals of North America: biology, management, and conservation, 2nd edn. Johns Hopkins University Press, Baltimore, pp 611-633

Gehrt SD (2004) Ecology and management of striped skunks, raccoons, and coyotes in urban landscapes. In: Fascione N, Delach A, Smith M (eds) Predators and people: from conflict to conservation. Island Press, Washington, DC, pp 81-104

Gehrt SD (2010) The Urban ecosystem. In: Gehrt SD, Riley SPD, Cypher BL (eds) Urban carnivores: ecology, conflict, and conservation. The Johns Hopkins University Press, Baltimore, pp 3-11

Gehrt SD, Fritzell EK (1996) Sex biased response of raccoons (Procyon lotor) to live traps. Am Midland Naturalist 135:23-32

Gehrt SD, Fritzell EK (1997) Sexual differences in home ranges of raccoons. J Mammal 78:921-931

Gehrt SD, Fritzell EK (1998) Duration of familial bonds and dispersal patterns for raccoons in South Texas. J Mammal 79:859-872

Gehrt SD, Anchor C, White LA (2009) Home range and landscape use of coyotes in a major metropolitan landscape: coexistence or conflict? J Mammal 90:1045-1057

Gliwicz J, Goszczynski J, Luniak M (1994) Characteristic features of animal populations under synurbization - the case of the Blackbird and of the Striped Field Mouse. Mem Zoologi 49:237-244

Grau GA, Sanderson GC, Rogers JP (1970) Age determination of raccoons. J Wildl Manag 34:364-372

Hadidian J, Prange S, Rosatte R, Riley SPD, Gehrt SD (2010) Raccoons (Procyon lotor). In: Gehrt SD, Riley SPD, Cypher BL (eds) Urban carnivores: ecology, conflict, and conservation. The Johns Hopkins University Press, Baltimore, pp 35-47

Heisey DM, Fuller TK (1985) Evaluation of survival and cause-specific mortality rates using telemetry data. J Wildl Manag 49:668-674

Hoffman CO, Gottschang JL (1977) Numbers, distribution, and movements of a raccoon population in a suburban residential community. J Mammal 58:623-636

Hooge PN, Eichenlaub B (1997) Animal movement extension to Arcview, version 1.1. Alaska Biological Science Center, US Geological Survey, Anchorage

Iossa G, Soulsbury CD, Baker PJ, Harris S (2010) A taxonomic analysis of urban carnivore ecology. In: Gehrt SD, Riley SPD, Cypher BL (eds) Urban carnivores: ecology, conflict, and conservation. The Johns Hopkins University Press, Baltimore, pp 173-180

Johnson DH (1980) The comparison of usage and availability measurements for evaluating resource preference. Ecology 61:65-71

Johnstone RF (2001) Synanthropic birds of North America. In: Marzluff JM, Bowman R, Donnelly R (eds) Avian ecology and conservation in an urbanizing world. Kluwer, Boston, pp 49-67

Lehman LE (1984) Raccoon density, home range, and habitat use on southcentral Indiana farmland (PitmanRobertson Bulletin No.15). Indiana Department of Natural Resources, Indianapolis

Maryland Department of Transportation-State Highway Administration (2007) Anne Arundel County, Maryland 2007 Traffic Volume Map. Baltimore, Maryland

McCleery RA, Lopez RR, Silvy NJ, Gallant DL (2008) Fox squirrel survival in urban and rural environments. J Wildl Manag 72:133-137 
McNay RS, Morgan JA, Bunnell FL (1994) Characterizing independence of observations in movements of Columbian black-tailed deer. J Wildl Manag 58:422-429

Mohr CO (1947) Table of equivalent populations of North American small mammals. Am Midland Naturalist 37:223-249

Otis DL, Burnham KP, White GC, Anderson DR (1978) Statistical inference from capture data on closed animal populations. Wildl Monogr 62

Ott P, Hovey F (1997) “bycompsas”, A Compositional Analysis Program. (URL http://nhsbig.inhs.uiuc.edu/ wes/habitat.html)

Page LK, Gehrt SD, Robinson NP (2008) Land-use effects on prevalence of raccoon roundworm (Baylisascaris procyonis). J Wildl Manag 44:594-599

Pickett STA, Cadensasso ML, Grove JM, Groffman PM, Band LE, Boone CG, Burch WR Jr et al (2008) Beyond urban legends: An emerging framework of urban ecology, as illustrated by the Baltimore Ecosystem Study. BioScience 58:139-150

Prange S, Gehrt SD (2004) Changes in mesopredator-community structure in response to urbanization. Can J Zool 82:1804-1817

Prange S, Gehrt SD, Wiggers EP (2003) Demographic factors contributing to high raccoon densities in urban landscapes. J Wildl Manag 67:324-333

Prange S, Gehrt SD, Wiggers EP (2004) Influences of anthropogenic resources on raccoon (Procyon lotor) movements and spatial distribution. J Mammal 85:483-490

Randa LA, Yunger JA (2006) Carnivore occurrence along an urban-rural gradient: a landscape-level analysis. J Mammal 87:1154-1164

Riley SPD, Hadidian J, Manski DA (1998) Population density, survival, and rabies in raccoons in an urban national park. Can J Zool 76:1153-1164

Riley SPD, Sauvajot RM, Fuller TK, York EC, Kamradt DA, Bromely C, Wayne RK (2003) Effects of urbanization and habitat fragmentation on bobcats and coyotes in Southern California. Conserv Biol $17: 566-576$

Rosatte RC (2000) Management of raccoons (Procyon lotor) in Ontario, Canada: Do human intervention and disease have significant impact on raccoon populations? Mammalia 64:369-390

Rosatte RC, Howard D, Campbell J, MacInnes CD (1990) Intramuscular vaccination of skunks and raccoons against rabies. J Wildl Dis 26:225-230

Rosatte RC, Power MJ, MacInnes CD (1991) Ecology of urban skunks, raccoons, and foxes in metropolitan Toronto. In: Adams LW, Leedy DL (eds) Wildlife conservation in metropolitan environments. National Institute for Urban Wildlife, Columbia, pp 31-38

Sanderson GC, Nalbandov AV (1973) The reproductive cycle of the raccoon in Illinois. Illinois Nat Hist Surv Bull 31:25-85

Schneider DG, Mech LD, Tester JR (1971) Movements of female raccoons and their young as determined by radiotracking. Anim Behav Monogr 4:1-43

Seaman DE, Millspaugh JJ, Kernohan BJ, Brundige GC, Radeke KJ, Gitzen RA (1999) Effects of sample size on kernel home range estimates. J Wildl Manag 63:739-747

United States Bureau of the Census (2000) Statistical abstract of the United States: 2000. United States Bureau of the Census, Washington, D.C

White GC, Garrott RA (1990) Analysis of wildlife radio-tracking data. Academic, San Diego

Withey JC, Marzluff JM (2009) Multi-scale use of lands providing anthropogenic resources by American crows in an urbanizing landscape. Landsc Ecol 24:281-293

Worton BJ (1989) Kernel methods for estimating the utilization distribution in home-range studies. Ecology $70: 164-168$ 